\title{
Hydrology Modelling-Based Biopore Infiltration Holes (BIH) Determination as River Flood Disaster Mitigation in Sewu Village, Surakarta, Central Java, Indonesia
}

\author{
Eka Wulan Safriani ${ }^{{ }^{*}}$, Anisaa Nur Halimah ${ }^{2}$, Yunus Aris Wibowo ${ }^{3}$ \\ 1,2,3 University Muhammadiyah of Surakarta, Indonesia
}

\begin{tabular}{ll} 
Article Info & Abstract \\
\cline { 1 - 2 } $\begin{array}{l}\text { Article History } \\
\text { Dikirim }\end{array}$ & $\begin{array}{l}\text { Sewu Village is annually experience by river flooding. The application of Biopore In- } \\
\text { filtration Holes (BIH) is one of the measures to reduce river flood disaster risk. This } \\
\text { Diterima }\end{array}$ \\
research was aimed to determine the proper location of the BIH. Hydrology tools by \\
using flow direction analysis was used to obtain the best place of BIH. It utilized Digital
\end{tabular}

(C) 2019 The Authors. Published by UNNES. This is an open access article under the CC BY license (http://creativecommons.org/licenses/by/4.0/)

\section{INTRODUCTION}

Indonesia is one of the vulnerable countries which possessed 2.862 disaster occurences in 2017. Flood disaster events dominated by $89,9 \%$ and $10,1 \%$ was covered by other disaster occurences. Surakarta is one of the most vulnerable city toward flood due to it is passed by four river, namely Bengawan Solo, Pepe, Jenes, and Anyar River. It causes 25 villages in Surakarta are indexed as flood-prone area (BPBD, 2017). Sewu Village is a part of Surakarta City which experiences by river flood annually.

Sewu Village is an urban area which takes possession of high population growth. It triggers the decrease of green open space extensive. Sewu Village covers 48,5 hectar area in width where settlements possess 29,79 hectar, services by 2,45 hectare, companies by 1,16 hectare, industries by 1,73 hectare, open space by 1 hectare, cemetery by 0.2 hectare, and another land utilization by 12.17 hectare (BPN, 2018). Urbanization generally increase every year which is caused by population growth and triggers run off increase, decrease

\footnotetext{
*E-mail : A610170016@student.ums.ac.id,2anisaanh45@gmail.com, 3yunusariswibowo@gmail.com

Address : Jl. Ahmad Yani, Pabelan, Kartasura, Surakarta, Central Java, Indonesia
}

of water infiltration, and flood as negative effect (Anggreaini, dkk, 2013).

Flooding is a common problem among the people which needs special attention. The best effort that can be conducted to reduce the level of disaster risk is by arrange a mitigation planning, either physically mitigation or even increase the people awareness and capacity to overcome the threats (BNPB, 2007). Flood disaster inundated Kampung Putat, Sewu Village on February 6, 2016 (Solopos.com, 2016), on November 28, 2017 floods also drowned the settlement in Sewu Villaged due to the overflowing of Bengawan Solo River (Republika.co.id, 2017) whereas on March 7, 2019, flood inundated 5 houses in Sewu village (Tribunnews.com, 2019). Those flood events indicate that Sewu Village needs for efforts to mitigate the flood disaster.

The application of Biopore Infiltration Holes (BIH) can be conducted as a mitigation planning in flood-prone areas. BIH as flood disaster mitigation is a low cost effort and it can be used as groundwater reserve. It can be applied by performing "one day for biopore" policy which is needed for all level society in every country ((Permatasari, 2015). Therefore, an appropriate technology for determining the proper location of $\mathrm{BIH}$ is necessary. This resep-ISSN 2549-3078 e-ISSN 2549-3094 
arch focused on Digital Elevation Model (DEM) utilization to find the lowest point as location of BIH. Data altitude (elevation) is a data point on the earth's surface elevation measured from above the sea level. Information altitude somewhere very important and can be used in various fields, including mapping of land resources, river network mapping, flood modeling and simulation, and the simulation of flow inundation area (Rustan, 2015). This study focuses on determining the exact location of LRB using hydrological modeling for flood mitigation in Sub Sewu.

\section{RESEARCH METHOD}

This research was conducted in Sewu Village, Jebres Subdistrict, Surakarta City $\left(7^{\circ} 31^{\prime} 41^{\prime \prime}\right.$ LS-

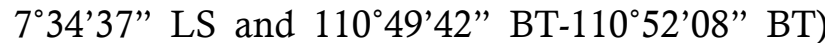
which bordered by Bengawan Solo and Pepe River. Showed DEM which was obtained from DEMNAS with 8.5 meter spatial resolution which covered Sewu Village. The data analysis technique used was hydrological modeling on the ArcGIS application by utilizing tool sink and flow direction. Sink was used to find out the lowest points on the ground surface, while the flow direction was used to determine the direction of water flow.

This research was qualitative study which used Geography Information System (GIS) for analyzing the proper location of biopore. Flow direction and Sink analysis were used to define the run off flow direction and the lowest point of Sewu Village area. The lowest point indicates the proper location of biopore.

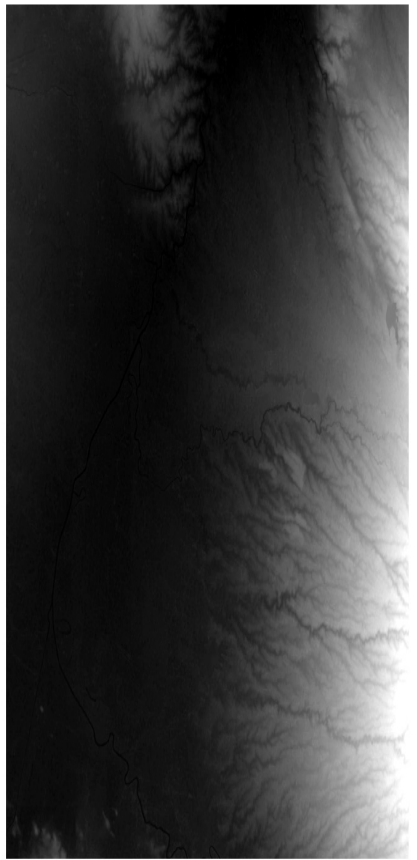

Fig 2. Digital Elevation Model of Sewu Village (Sumber: DEMNAS, 2019)

This research is a descriptive qualitative study using flow direction analysis through the management of 2019 DEM data to determine the direction of surface flow. The DEM data used has a detailed 8.5 meter detail. In processing the data is processed using a sink to find out the lowest point. The results of processing obtained a number of location points with the lowest surface flow.

The step of this research begins with downloading the DEM data, then processing it using ArcGIS. This DEM contains the research area to

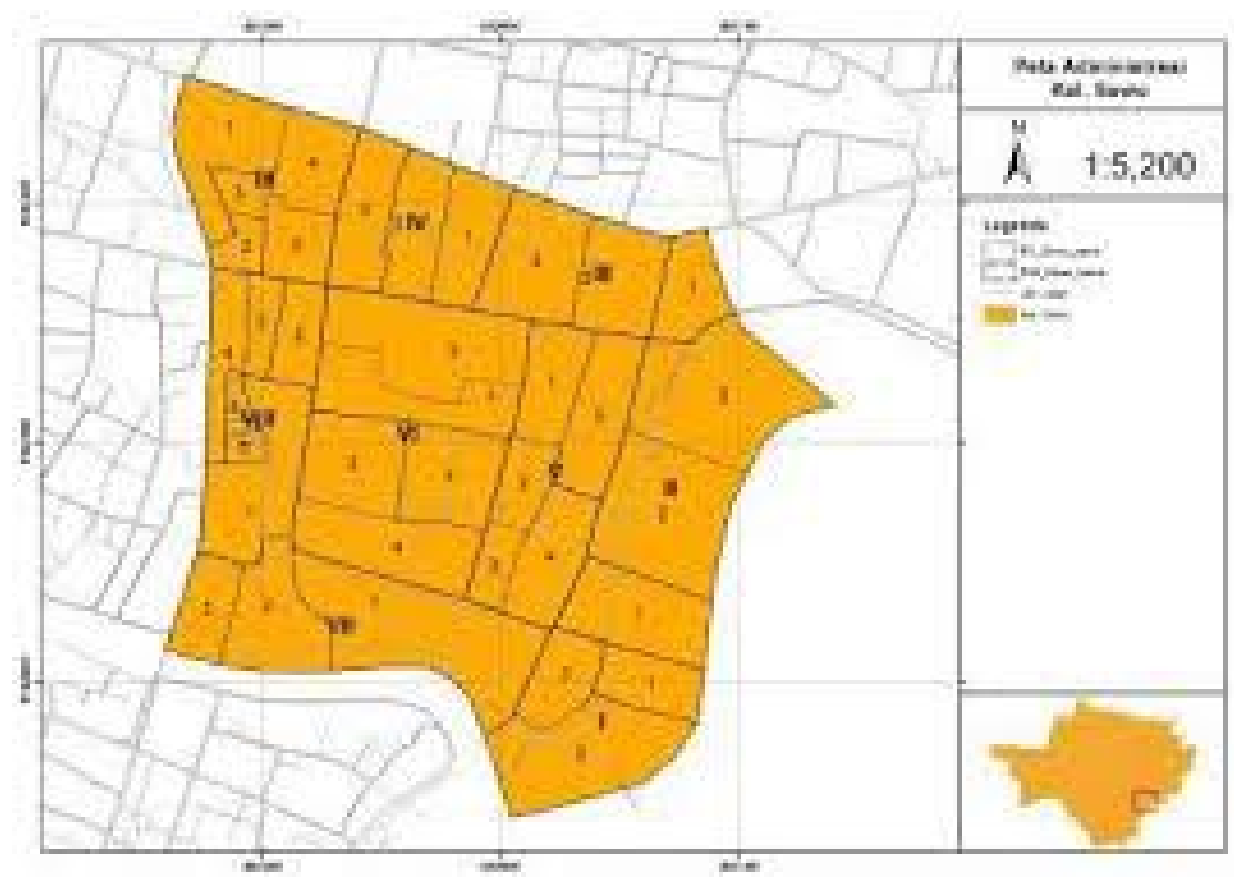

Fig 1. The Research Map of Location (Sumber: Rufia Andisetyana, 2018) 
be mapped to find the lowest point. The lowest point is based on SINK which is obtained from the processing results. In addition, observation methods are used to obtain additional information. Observation is done by observing directly to the location of the lowest point that has been mapped. Based on the results of analyzing lowest points found are presented in the following diagram. The assumption used was that water will flow towards the lowest points so that these points are suitable locations for making biopori holes.

Table 1. The elevation of lows point

\begin{tabular}{cccc}
\hline Point & Elevation & Point & Elevation \\
\hline 1 & 80.96 & 21 & 86.36 \\
2 & 88.54 & 22 & 87.11 \\
3 & 88.24 & 23 & 88.28 \\
4 & 87.23 & 24 & 87.79 \\
5 & 87.05 & 25 & 87.62 \\
6 & 79.6 & 26 & 88.07 \\
7 & 87.94 & 27 & 87.38 \\
8 & 88.01 & 28 & 86.6 \\
9 & 79.35 & 29 & 88.2 \\
10 & 88.03 & 30 & 90.6 \\
11 & 87.71 & 31 & 88.54 \\
12 & 87.71 & 32 & 86.88 \\
13 & 87.01 & 33 & 85.94 \\
14 & 90.13 & 34 & 87.4 \\
15 & 86.31 & 35 & 85.58 \\
16 & 86.02 & 36 & 87.29 \\
17 & 88.02 & 37 & 88.9 \\
18 & 88.61 & 38 & 88.05 \\
19 & 89.14 & 39 & 88.46 \\
20 & 85.95 & 40 & 87.59 \\
41 & 87.87 & 43 & 87.58 \\
42 & 88.6 & 44 & 88.31 \\
\hline
\end{tabular}

\section{RESULT AND DISCUSSION}

The analysis showed that Sewu Village is an urban area with densely-populated and annually experienced by river flooding. It was caused by disruption of drainage system. Therefore, BIH is properly applied in Sewu Village as flood disaster mitigation. The proper location of BIH is the best location based on hydrology modelling using GIS (flow direction and sink).

Sanitya et. al (2014) stated there were three indicators to define the proper location and the number of $\mathrm{BIH}$ in Bandung City, Indonesia, namely existing condition of $\mathrm{BIH}$, defining the best location, and determining the number of $\mathrm{BIH}$. In
Bandung City there were only a few of BIH, it was not ideal for mitigation planning, so that there were performed an application of BIH determination in Cikapundung based on run off direction. Meanwhile, the number determination was conducted by analysis of precipitation, run off, and infiltration rate.

This research used hydrology modelling by using GIS to simplify the process because of unavailibility of rainfall and run off data. The application of GIS in determining watershed's physical parametercharacteristic is able to deriveunit hydrograph of GIUH method with limited hydrologic data or unavailability of rainfall-runoff data.The unit hydrograph modeling by GIUH and Nash model approach conducted on Keduang and Wirokowatershedsfound smallerQp,later tpandlonger tbthan by the observed unit hydrograph. The accuracy analysis shows the rainfall-runoff simulation in Keduang watershed gives good and satisfying results, while in Wirokowatershed the results areless good and satisfying. Results of the sensitivity analysisshow thatRLparameter and kparameter of Nashmodel affect the shape of GIUH unit hydrograph (Sulisyowati A, 2018).

DEM is a spatial raster data which is extracted using high pass and filtering in GIS software. It experiences different process of upper and lower area (various altitude). Ground elevation of sertain area is showed by pixel values. Furthermore, the DEM was processed and analyzed using flow direction to find out the run off direction. The flow direction results was processed using sink to defind the lowest point as proper location of BIH. There were 44 points and they were arranged as tentative map of $\mathrm{BIH}$ location.

DEM data that has been extracted is analyzed using analysys hydrology tools, namely flow direcrion to determine the direction of surface flow. In principle, flow direction data is obtained from the manifestations of topographical conditions that are described in the form of morphometric features. Based on the results of the analysis process the results of the direction of the lowest point of the surface studied are obtained. The direction data for the lowest point is visualized in the following figure,

Those 44 points were the lowest location and appropriate with $\mathrm{BIH}$. A total of 44 points are the lowest points identified as flood prone points. Therefore the location point is very appropriate as the location for making LRB. With the mapping of the location of the LRB making it can be used optimally the benefits of the LRB itself. So far, the making of LRB conducted in the community generally 
does not pay attention to the analysis of hydrology tools, so that the function of the LRB itself is not optimal.

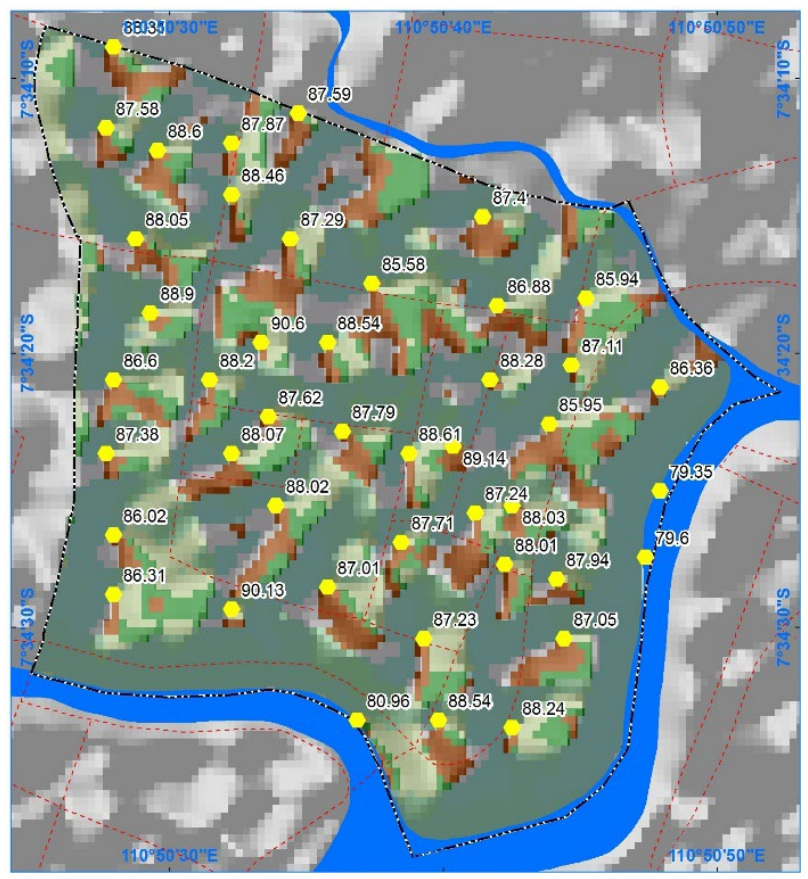

Fig 3. Results mapping of Analysis flow direction of Sewu village

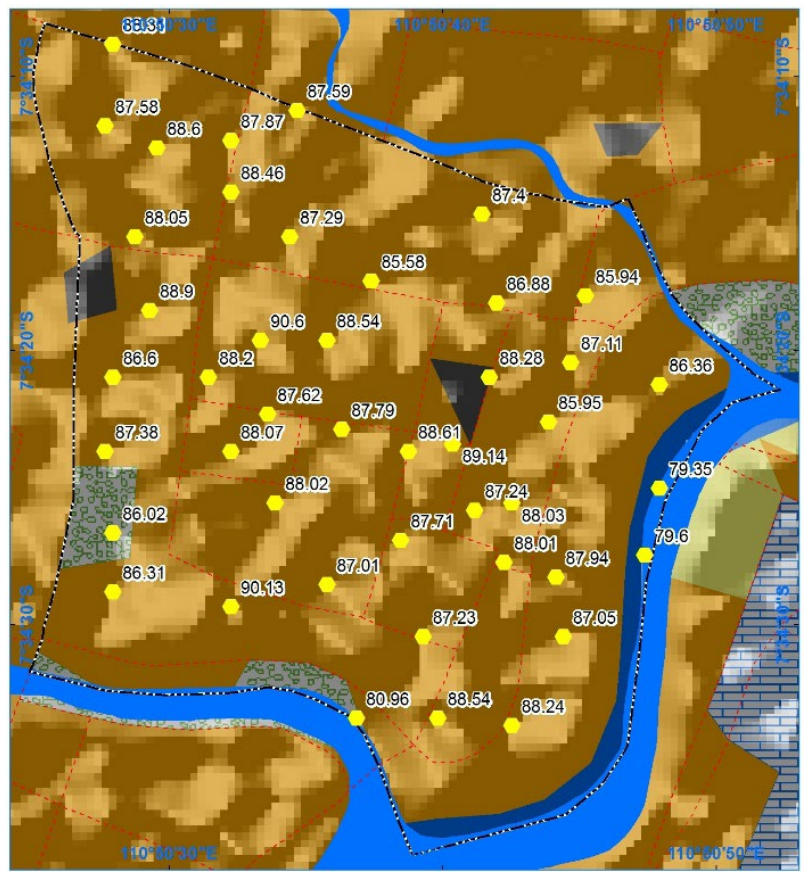

Fig 4. Results mapping of Analysis flow direction of Sewu village base on land use

Therefore the existence of an analysis of hydrology tools is obtained by the exact location points optimally. In another study, it was explained that the watershed boundaries were measured by connecting the highest points between the water- sheds with one another. The delineation process is carried out automatically through an algorithm with the principle of topographic data extraction to obtain hydrological parameters of a watershed. The parameters consist of flow direction, flow accumulation, river order (stream order), and basin. Logically, the DEM data input with a resampling treatment will result in a watershed boundary that is more relevant to the field conditions compared to the watershed delineation process from the DEM data input without resampling treatment. Based on the hydrological characteristics of a region, thus the results of the watershed boundary delineation process from DEM data input with resampling treatment are considered to produce more accurate information (Nugroho et al., 2018).

\section{CONCLUTION}

The results of the analysis of hydrology tools using flow direction and management of geographic information systems through DEM data indicate that 44 points found are points of puddle of water. So it is necessary to implement the LRB at that point as a flood disaster mitigation effort. With this application, it can be used as a solution to minimize the occurrence of flooding in Sewu Village, Jebres District, Surakarta City.

\section{ACKNOWLADGEMENT}

The researcher would like to thank all those who have supported the research process. This activity was supported by all research respondents, namely the Sewu Village community, and the Geography Education Study Program Lecturer / Supervisor Team, Surakarta Muhammadiyah University and research colleagues. Geography Education Study Program, Surakarta Muhammadiyah University for their cooperation and support.

\section{REFERENCES}

Anggraeni, M. et al. 2013. The Effectiveness of Bio-pore as an Alternative Eco drainage Technology to Control Flooding in Malang City. Jurnal of Applied Environmental and Biological Scienses. 3(2),23-28.

Badan Nasional Penanggulangan Bencana (BNPB). 2017. Data Bencana Indonesia 2017. Penerbit Pusat Data, Informasi dan Humas Badan Nasional Penanggulangan Bencana Juni 2018:Jakarta.

Permatasari, L. 2015. Biopore Infiltration Hole: "One Day for Biopore" as an Altertnative Prevent Flood. Proceedings of Ninth The IIER International Conference, Bangkok. 7 February 2015, Bangkok Thailand.

Purwono, N. dkk. 2018. Teknik Filtering Model Elevasi Digital (DEM) untuk Delineasi Batas Daerah Aliran Sungai (DAS). Prosiding Seminar Nasional Geografi UMS IX 2018.

Rahanjani, Y.E. et al. 2012. Pemanfaatan Citra Digital Eleva- 
tion Model (DEM) untuk Studi Evolusi Geomorfologi Gunung Api Merapi Sebelum dan Setelah Erupsi Gunung Merapi 2010. Seminar Nasional Informatika UPN Veteran Yogyakarta 30 Juni 2012.

Rustan., Purqon, A. 2015. Analisis Penambahan Resolusi Digital Elevation Model (DEM) dengan Menggunakan Metode Interpolasi Inverse Distance Weighted (IDW) utuk Aplikasi Analisis Potensi Longsoran. Prosiding SKF 2015. 16-17 Desember 2015.

Sanitya, R.S. dkk. 2014. Penentuan Lokasi dan Jumlah Lubang Resapan Biopori di Kawasan DAS Cikapundung Bagian Tengah. Jurnal Perencanaan Wilayah dan Kota. 13(1). 